\title{
Reconstructing Deweyan Growth: The Significance of James Baldwin's Moral Psychology
}

\author{
Jeff Frank
}

\section{AbSTRACT}

In this paper I raise and respond to the question: Is John Dewey's understanding of growth sufficiently responsive to problems associated with race and racism? I begin with a discussion of Dewey's essay "Racial Prejudice and Friction," and show that Dewey lets a major objection to his response to racism and prejudice stand without comment. By focusing on this objection I will show that-by Dewey's own admission-one cannot grow morally without confronting aspects of moral psychology that Dewey downplayed in offering his response to racism. I will then show that James Baldwin's work offers resources that help us confront these aspects of moral psychology, and argue that bringing Dewey in conversation with Baldwin allows us to reconstruct our understanding of growth so that it becomes more responsive to problems associated with race and racism.

In this paper I raise and respond to the question, Is John Dewey's understanding of growth sufficiently responsive to problems associated with race and racism? A growing number of scholars have asked similar questions of Dewey's philosophy. ${ }^{1}$ These scholars generally start with an expression of disappointment-how could someone so concerned with social issues devote so little attention to the problem of racism-and conclude with some variant of the following: While Dewey's philosophy offers us resources that can help as we construct responses to problems of race and racism, his philosophy needs to be reconstructed (often by placing it in conversation with texts that more explicitly address these problems) in order to do so. ${ }^{2}$ This will, in large part, be the approach I take in this paper. I begin with a discussion of Dewey's essay "Racial Prejudice and Friction," and show that Dewey lets a major objection to his response to racism and prejudice stand without comment. By focusing on this objection I will show that-by Dewey's own admission-one cannot grow morally without confronting aspects of moral psychology that Dewey downplayed in offering his response to racism. I will then show that James Baldwin's work offers resources that help us confront these 


\section{JefF Frank}

aspects of moral psychology, and argue that bringing Dewey in conversation with Baldwin allows us to reconstruct our understanding of growth so that it becomes more responsive to problems associated with race and racism.

\section{John Dewey's Response to Racism}

Gregory Pappas and Sharon Sullivan offer interpretations of "Racial Prejudice and Friction" that are largely consonant, though they draw different conclusions from this shared understanding. ${ }^{3}$ Both Pappas and Sullivan argue that Dewey's response to racism is marked by four central elements: (1) economic and political arrangements must be reconstructed so that (2) proximity of different racial groups will lead to communication and community (not the fear, conflict and mutual hostility that exists under current arrangements) that will (3) reform and reconstruct habits of interaction between individuals from different races so that we might (4) develop ethical and educative relations between individuals from different races. As Pappas notes, Dewey's framework may be insufficient to all of the problems associated with race and racism, but it has the virtue of acknowledging the difficulty of these problems while also suggesting a flexible yet action-guiding framework that can help motivate us to experiment with our current economic and political thinking, policies and actions. While Sullivan doesn't think we should reject Dewey's framework, she thinks it needs to be expanded because Dewey conflates racism with ethnocentrism, thereby holding the mistaken view that "all prejudice is borne out of unfamiliarity with different groups."4 More, she argues that,

Nowhere in it ["Racial Prejudice and Friction"], however, does Dewey challenge, or even indicate awareness of, the white privileged perspective that operates within it. He drastically underestimates the obstacles to transformation that one's unconscious might erect, obstacles that are all the more effective because they are not the product of conscious deliberation. ${ }^{5}$

While I agree with this line of criticism, I don't think Dewey-as Sullivan assertsis unaware of it. As I will show below, he raises this very objection in the essay. Yet even though he recognizes the objection, this doesn't alter his framework. As such, I agree with Sullivan that Dewey underestimates the power of racism against blacks in America by conflating it with the attitudes that Americans hold towards individuals from other cultures, and he similarly underestimates the unconscious beliefs that keep many Americans from acknowledging, let alone questioning, their own racist beliefs, practices and policies.

The passage that I turn to as evidence of Dewey's recognition of Sullivan's main line of criticism comes towards the middle of the essay. After voicing general optimism that individuals from historically conflicting groups can find a way towards community and communication, Dewey wonders if white Americans can indeed participate in this type of activity: 
The other consequence concerns the psychological effect of rule upon the dominant political group. Arrogance and contempt are fostered. Moreover we also hate those whom we have wronged. There is the feeling, for example, that the Negroes must be intrinsically a servile people because they allowed themselves to be held in slavery. If they had been equal to Anglo-Saxons, the argument usually runs, they would have fought to the point of extermination rather than have endured the servile status.... The disdain and contempt of the overlord class for the inferior is moreover usually complicated by an uneasy subconscious feeling that perhaps the subject people is not really so inferior as its political status indicates. Then the expression of superiority assumes a noisy and aggressive form on the psychological principle that the "lady protests too much." An assured superiority would be more calmly complacent. ${ }^{6}$

In this description of the moral psychology of racism, Dewey broadens the types of issues that need to be understood if problems of racism are to be adequately addressed. For example, Dewey notes that the dominant group must work through their arrogance and contempt. ${ }^{7}$ More, the dominant group holds a strong but irrational hatred for the group that it has wronged, and this hatred can be expressive of a subconscious feeling that the wronged are really not as inferior as their political status indicates. Here Dewey appears to raise Sullivan's points of criticism, but somehow he doesn't let this line of criticism affect his thinking on how we are to work against racism. It may be the case that Dewey underestimates the number of individuals who are trapped by the racist moral psychology he accurately diagnoses. In his belief in the promise of moral progress, Dewey may not appreciate the strength, scope and staying power of racism and its attendant moral psychology. While this hope serves its purpose - it can motivate individuals to attempt the work of unlearning racism in the face of a more inclusive, democratic aim ${ }^{8}$-it should not keep us from acknowledging the difficulty of the task. ${ }^{9}$

In the next section, I develop a moral psychology that maintains Dewey's hope while more fully acknowledging the moral psychology of racism. By expanding Dewey's diagnosis of racism, and by more fully appreciating the effort it will take to overcome it, James Baldwin's work offers us an opportunity to reconstruct what it means to grow as an individual called on to address our own racism and the problems of racism in society.

\section{James Baldwin on Race And Racism}

Although Baldwin is primarily recognized as a writer of fiction and essays, a growing number of philosophers and political theorists are beginning to take his work seriously on questions and issues of race and racism. ${ }^{10}$ The interest in Baldwin shown by these commentators has, for the moment, not carried over into conversations in the philosophy of education. ${ }^{11}$ This is unfortunate, as I hope to illustrate below, 


\section{JEFF FRANK}

because Baldwin offers a compelling account of racism that stands as an important and significant corrective to Dewey's insufficiently critical vision of how racism is to be addressed. At the center of Baldwin's account is his diagnosis of the myth of white innocence. While innocence is often contrasted with guilt, Baldwin' aim is not (as it were) to burden his readers with a guilty conscience. Instead, Baldwin challenges us to do the far more difficult thing: to work from innocence and to a place where growth and maturity are possible. Guilt is not a requirement for this type of growth and maturity, but growth and maturity-as I will show in more detail below-is impossible if white Americans continue to evade the reality of racism and its continuing significance. ${ }^{12}$

\subsection{The Myth of White Innocence}

White innocence is a topic Baldwin addresses across his writing career, and it is not easily captured in a definitive statement. Instead, white innocence is a nest of conscious and unconscious beliefs and feelings that are expressed in overtly and covertly racist language, actions and policies. At its core, though, stands a pernicious belief that there is a causal relationship between prosperity-wealth, power, social standing - and moral goodness. That is, white innocence revolves around the belief that individuals with power deserve it because they are morally good, and anyone without power is also, therefore, morally bad. Following this logic, because white Americans hold the most power in the world they are also the most moral people in the world. Baldwin is not, importantly, only interested in exposing the hypocrisy of this type of view. Showing that prosperity is often built and sustained by immoral acts-slavery, colonialism, violence-is far too obvious, to Baldwin, to merit sustained comment. What interests Baldwin are the effects of taking an idea like this seriously: the life one leads if this is-even if unconsciously-one's guiding moral ideal. In an early essay, "Stranger in the Village," Baldwin writes,

Most people are not naturally reflective any more than they are naturally malicious, and the white man prefers to keep the black man at a certain human remove because it is easier for him thus to preserve his simplicity and avoid being called to account for crimes committed by his forefathers, or his neighbors. He is inescapably aware, nevertheless, that he is in a better position in the world than black men are, nor can he quite put to death a suspicion that he is hated by black men therefore. He does not wish to be hated, neither does he wish to change places, and at this point in his uneasiness he can scarcely avoid having recourse to those legends which white men have created about black men, the most usual effect of which is that the white man finds himself enmeshed, so to speak, in his own language which describes hell, as well as the attributes which lead one to hell, as being black as night. ${ }^{13}$ 
In this passage Baldwin illustrates the complexity and difficulty of holding onto white innocence in the face of overwhelming evidence to its contrary. The white man knows that he wouldn't want to change places with the black man, and he fears that his position in society may have been established, not by the moral strength and virtuous acts of his forefathers, but by dint of crime. Not wanting to deal directly with that fear, to work through the myths of white innocence, he invents a contrasting myth (the violent, the sexual, the dangerous black man) ${ }^{14}$ that allows him to return to his simplicity, purity and innocence. Sadly, as Baldwin makes us painfully aware, the myths that the white world creates about the black world keep those who subscribe to those myths enmeshed in stories, feelings and beliefs that distort and hide reality. White innocence, then, gives rise to feelings of purity and simplicity that keep those under its influence from the truth. ${ }^{15}$

\subsubsection{Purity and Simplicity}

Importantly, what is salient about white innocence is not its almost immediately apparent hypocrisy. Rather, what is significant is what it creates. The individual under its influence knows-but cannot acknowledge ${ }^{16}$ - that something is terribly amiss. Again, instead of working towards what is really at issue, the individual retreats into myths. Because these myths are even harder to sustain than that which gave rise to them, the individual is forced to (as it were) dig in: to become entrenched; to close off; to become embattled. As Baldwin writes, "No one is more dangerous than he who imagines himself pure in heart: for his purity, by definition, is unassailable. ${ }^{17}$ Pointing out the flaws of someone who believes that she is pure of heart-even using her own definitions of what counts as being flawed-is not productive, according to Baldwin, because that person is not interested in what is the case. She is interested in producing, reproducing, protecting and promoting her flawed vision of reality. Someone like this is dangerous because he or she has given up on the difficult pursuit of truth and justice under the false assumption that she is already there. Baldwin makes a related point:

Americans, unhappily, have the most remarkable ability to alchemize all bitter truths into an innocuous but piquant confection and to transform their moral contradictions, or public discussions of such contradictions, into a proud decoration, such as are given for heroism on the field of battle. ${ }^{18}$

Instead of engaging what is actually at issue-a certain uneasiness about one's own privilege, a certain uneasiness about one's race, a certain uneasiness about how race, privilege and morality interact-we deflect our uneasiness, ${ }^{19}$ transforming it into something that we can get behind; something that we can fight for; something that makes us feel like an approximation of a hero on a field of battle. We avoid, or evade, the difficult source of our confusion and uncertainty about the interrelations between race, privilege and morals, and engage in what often amounts to 


\section{JEFF FRANK}

a high-minded condemnation of an entire race of people. But, as Baldwin so astutely diagnoses,

In overlooking, denying, evading his [a black American's] complexitywhich is nothing more than the disquieting complexity of ourselves-we are diminished and we perish; only within this web of ambiguity, paradox, this hunger, danger, darkness, can we find at once ourselves and the power that will free us from ourselves. ${ }^{20}$

Although we may feel a momentary rush of virtue in condemning our falsified view of the other, and although we can fight valiantly to preserve our sense of high-mindedness, this way of living dooms us to delusions that we cannot extricate ourselves from. So caught, we can never experience moral maturity and moral growth. In order to grow, we must make the difficult return to reality: letting loose of the myth of white innocence, and facing up to the ambiguity, paradox, danger, and darkness of moral life.

\subsubsection{Returning to Reality}

Baldwin works to get his reader to a point where he or she feels compelled to choose between the myths that sustain a false sense of virtue and a confrontation with the difficulty of reality. One strategy he uses is exhortation. Thus, in The Fire Next Time, he wants his reader to see that the myths we cling to have the potential to destroy us. For example, if the Black Muslim [Nation of Islam] continues to believe that the white man is the devil, and the white world continues to believe that the living conditions in some predominately black neighborhoods-like Baldwin's Harlem-can be chalked up to lack of virtue on the part of its black inhabitants, then violence and strife lie in wait. But, he tells us, we can get out from under these myths: "We are capable of bearing a great burden, once we discover that the burden is reality and arrive where reality is." ${ }^{21}$ This process will not be easy, and it will cause those who succumb to a belief in-for example - the inherent superiority or inferiority of an entire race of people, a great deal of confusion and anxiety. Nonetheless, we must confront reality. Moving from the extortive to the descriptive, Baldwin suggests, in some passages, that we have no other choice but to confront reality, despite our best evasive efforts. In “The Black Boy Looks at the White Boy," Baldwin writes,

This is not the way this truth presents itself to white men, who believe the world is theirs and who, albeit unconsciously, expect the world to help them in the achievement of their identity. But the world does not do this-for anyone; the world is not interested in anyone's identity. And, therefore, the anguish which can overtake a white man comes in the middle of his life, when he must make the almost inconceivable effort to divest himself of everything he has ever expected or believed, when he must take himself apart and put himself together again, walking out of the world, into limbo, or into what certainly looks like limbo. ${ }^{22}$ 
Building on this passage, the middle-aged white man who has always experienced prosperity has also-even if only unconsciously-assumed that he was virtuous. But-as Baldwin has already shown - the direct causal link between virtue and prosperity is suspect, and an unknowing subscription to this belief can cause a great deal of unease when the belief is called into question. When the middle-aged man can no longer claim virtue with absolute certainty, when he realizes that his identity is his to be found, made, and earned, then it can feel as if he is entering a kind of limbo. He may wish to return to the myths that sustained his virtue, but he cannot: he has found reality, and it is his to live the acknowledgement of that reality.

\subsection{Growth}

When we realize that the myths that sustained us for so long are no longer sustainable, we are left in the state of limbo that Baldwin describes above. Baldwin describes his own experience of limbo in The Fire Next Time. Looking for something that would make sense of his life for him, Baldwin entered the church as a child preacher. Though this life gave him a certain prestige in his neighborhood and a certain power over his father, he realized that the enterprise was-for him-a sham. The pulpit kept him from a confrontation with his own life and what matters to him. Instead of facing his sexuality, his race, his country, his father, he embraced the church. After freeing himself from the church, he reclaimed responsibility for finding his own way in the world. His description of Elijah Mohammed and his followers in The Fire Next Time is a striking reminder that-though he agreed with many of the things Mohammed says-Baldwin would not abdicate responsibility for his own growth to anyone. He writes,

It is the responsibility of free men to trust and to celebrate what is constant-birth, struggle, and death are constant, and so is love, though we may not always think so-and to apprehend the nature of change, to be able and willing to change. ${ }^{23}$

We must be willing to change, because the things that matter in life-birth, struggle, death, love-are dynamic, and they call on us to be responsive to change and changes, and so they call us to change. While talk of love and birth and struggle may strike readers as somehow out of line in serious discussions about the moral life, ${ }^{24}$ Baldwin wants his readers to refocus on the importance of love in our life as a way of turning us towards an acceptance of responsibility for growth:

I use the word "love" here not merely in the personal sense but as a state of being, or a state of grace-not in the infantile American sense of being made happy but in the tough and universal sense of quest and daring and growth. ${ }^{25}$

Love is not purity or innocence, and it is not the given birthright of the prosperous or the downtrodden. Instead, love is a type of growth: a process that calls on 
us to turn away from sustaining-but ultimately destructive-myths, undergoing what can feel like limbo, so that we can face up to what we know to be problems in our life and in our life with others. One of the major problems that Americans face is the continuing significance of racism and racist policies. ${ }^{26}$ While we can pretend that this is not the case, we know that doing so would be evasive. We must work through our racism and the racism of our society, and we must try to grow through — not around, or in willful ignorance of-all of the difficult thoughts, emotions, and tensions that this work will invariably evoke. Hoping that good policy or good intentions will substitute for this struggle towards growth gets us in the state we remain in, almost one hundred years after Dewey's "Racial Prejudice and Friction": uneasy with our feelings about race, uneasy with how race is talked about in public and private, uneasy teaching students of different races, uneasy in daily interactions across racial lines. ${ }^{27}$

\section{Conclusions}

John Dewey clearly knows that the fact of growth and change is as much an intellectual as it is a social and moral issue. What I hope to have shown in section one of this paper is that Dewey did not fully appreciate the moral psychology of racism. While Dewey acknowledges that racism influences aspects of our moral psychology-it can breed arrogance, contempt, and provoke a noisy aggressiveness-he doesn't use this acknowledgement as a means to reconstructing his own thinking on racism. Because of this, Dewey underestimates its difficulty. His solution to the problems of racism-the implementation of redistributive economic policies and increased social contact between the races-seem doomed to failure if society is caught in the grip of the myth of white innocence. If this is the case-if Baldwin's diagnosis of American society is accurate-then we might begin to wonder just how significant Dewey's failure to account for the tenacious hold of racism may be. If racist moral psychology can effectively marshal myth to silence many of the facts it is presented with; if racist moral psychology can create ways of avoiding self-criticism and self-reflection; if racist moral psychology can shut off learning from the non-white contacts of life, we might worry: Can Dewey's educational project get off the ground under these conditions? I can't answer this question definitively, but if my reading of Baldwin's significance is compelling, educators should be concerned that if the moral psychology of racism is not adequately addressed, our best hopes for a reconstructed democracy will remain unrealized. Yet, if we learn from Baldwin's writing, we can reconstruct what growth means, and we can-in turn—see new ways of renewing Dewey's educational project. With a better understanding of the moral psychology of racism, we can appreciate how challenging it will be to create environments and opportunities that cause individuals to trade the delusion of innocence for the possibility of growth. 


\section{BiBLIOGRAPHY}

Alexander, Michelle. The New Jim Crow: Mass Incarceration in the Age of Colorblindness. New York: New Press, 2010.

Anderson, Elizabeth. The Imperative of Integration. Princeton, NJ: Princeton University Press, 2010.

Arendt, Hannah. "The Meaning of Love in Politics: A Letter by Hannah Arendt to James Baldwin." Journal of Political Thinking 2, no. 1 (2006). http://www. hannaharendt.net/index.php/han/article/view/95/156

Baldwin, James. Collected Essays. New York: Library of America, 1988.

Balfour, Lawrie. The Evidence of Things Not Said: James Baldwin and the Promise of American Democracy. Ithaca, NY: Cornell University Press, 2001.

Brown, Anthony. "Same Old Stories': The Black Male in Social Science and Educational Literature, 1930s to the Present." Teachers College Record 113, no. 9 (2011).

Cavell, Stanley. The Claim of Reason. New York: Oxford University Press, 1979.

Cerbone, David. "The Limits of Conservatism: Wittgenstein on 'Our Life' and 'Our Concepts." In The Grammar of Politics: Wittgenstein and Political Philosophy, edited by Cressida Heyes, 43-62. Ithaca, NY: Cornell University Press, 2003.

Cochran-Smith, Marilyn. "Learning and Unlearning: The Education of Teacher Educators," Teaching and Teacher Education 19 (2003): 5-28. http://dx.doi. org/10.1016/S0742-051X(02)00091-4

Dewey, John. "Racial Prejudice and Friction." In John Dewey: The Middle Works: 1899-1924, edited by Jo Ann Boydson, 13:242-54. Carbondale, IL: Southern Illinois University Press, 1988.

_- - Ethics. Vol. 7 of John Dewey: The Later Works: 1925-1953, edited by Jo Ann Boydson. Carbondale, IL: Southern Illinois University Press, 1985.

Diamond, Cora. "The Difficulty of Reality and the Difficulty of Philosophy." In Philosophy and Animal Life. New York: Columbia University Press, 2008.

Eldridge, Michael. "Challenging Speculations about 'Dewey's Racialized Visions."' Educational Theory 60, no. 4 (2010): 503-17. http://dx.doi.org/10.1111/j.17415446.2010.00372.x

Frank, Jeff. "Can Perfectionism Withstand the Acknowledgment of Slavery?" Philosophy of Education Yearbook 2011 (2011): 381-87.

- - - "James Baldwin's 'Everybody's Protest Novel': Educating Our Responses to Racism." Educational Philosophy and Theory, accessed May 16, 2011, http:// dx.doi.org/10.1111/j.1469-5812.2011.00776.x.

Fricker, Miranda. Epistemic Injustice: Power and the Ethics of Knowing. New York: Oxford University Press, 2007.

- - - "Feminism in Epistemology: Pluralism Without Postmodernism." In The Cambridge Companion to Feminism in Philosopy, edited by Miranda Fricker and Jennifer Hornsby, 146-55. New York: Cambridge University Press, 2000. 
Glaude, Eddie. In a Shade of Blue: Pragmatism and the Politics of Black America. Chicago: Chicago University Press, 2007.

Lawson, Bill, and Donald Koch, Pragmatism and the Problem of Race. Bloomington, IN: Indiana University Press, 2004.

MacMullan, Terrance. Habit of Whiteness: A Pragmatist Reconstruction. Bloomington, IN: Indiana University Press, 2009.

Margonis, Frank. "John Dewey's Racialized Visions of the Student and Classroom Community." Educational Theory 59, no. 1 (2009): 17-39. http://dx.doi. org/10.1111/j.1741-5446.2009.00305.x

Pappas, Gregory. "Dewey's Philosophical Approach to Racial Prejudice," Social Theory and Practice 22, no. 1 (1996).

Shulman, George. American Prophecy: Race and Redemption in American Political Culture. Minneapolis: University of Minnesota Press, 2008.

Spelman, Elizabeth. "Managing Ignorance." In Race and Epistemologies of Ignorance, edited by Sharon Sullivan and Nancy Tuana. Albany, NY: SUNY Press, 2007.

Stack, Sam F., Jr. "John Dewey and the Question of Race: The Fight for Odell Waller." Education and Culture 25, no. 1 (2009): 17-35.

Sullivan, Sharon. "From the Foreign to the Familiar: Confronting Dewey Confronting 'Racial Prejudice." The Journal of Speculative Philosophy 18, no. 3 (2004): 193-202.

- - - " "(Re)construction Zone: Beware of Falling Statues." In In Dewey's Wake: Unfinished Work of Pragmatic Reconstruction, edited by William Gavin. Albany, NY: SUNY Press, 2003.

Turner, Jack. "Awakening to Race: Ralph Ellison and Democratic Individuality." Political Theory 36, no. 5 (2008): 655-682. http://dx.doi.org/10.1177/0090591708321031 Williams, Patricia. Seeing a Color-Blind Future: The Paradox of Race. New York: Farrar, Straus and Giroux, 1998.

\section{Notes}

1. See, for examples, Gregory Pappas, "Dewey's Philosophical Approach to Racial Prejudice," Social Theory and Practice 22, no. 1 (1996); Sharon Sullivan, "(Re)construction Zone: Beware of Falling Statues," in In Dewey's Wake: Unfinished Work of Pragmatic Reconstruction, ed. William Gavin (Albany, NY: SUNY P., 2003); Sharon Sullivan, "From the Foreign to the Familiar: Confronting Dewey Confronting 'Racial Prejudice," The Journal of Speculative Philosophy 18, no. 3 (2004); Bill Lawson and Donald Koch, Pragmatism and the Problem of Race (Bloomington, IN: Indiana University Press, 2004); Eddie Glaude, In a Shade of Blue: Pragmatism and the Politics of Black America (Chicago: Chicago University Press, 2007); Sam Stack Jr., "John Dewey and the Question of Race: The Fight for Odell Waller," Education and Culture 25, no. 1 (2009); Terrance MacMullan, Habit of Whiteness: A Pragmatist Reconstruction (Bloomington, IN: Indiana University Press, 2009).

2. An exception to this is Frank Margonis, "John Dewey's Racialized Visions of the Student and Classroom Community, Educational Theory 59, no. 1 (2009). Margonis finds Dewey's philosophy insufficient to problems of racism, if not itself racist. Michael Eldridge 
in "Challenging Speculations about 'Dewey's Racialized Visions," Educational Theory 60, no. 4 (2010) has shown the many flaws in this line of thinking. While I will not rehearse all of Eldridge's points here, I note that I agree with Eldridge and find that Margonis's reading of Dewey is not only uncharitable, it is wrong.

3. Pappas, "Racial Prejudice," and Sullivan, "Foreign to Familiar."

4. Sullivan, "Foreign to Familiar," 199.

5. Ibid., 200.

6. John Dewey, "Racial Prejudice and Friction," in John Dewey: The Middle Works: 1899-1924, Volume 13, ed. Jo Ann Boydson (Carbondale, IL: Southern Illinois University Press, 1988), 248.

7. For a similar argument, see Dewey's Ethics: "A shrewd observer of political life remarked that power is poison. It is difficult for a person in a place of authoritative power to avoid supposing that what he wants is right as long as he has power to enforce his demand. And even with the best will in the world, he is likely to be isolated from the real needs of others, and the perils of ignorance are added to those of selfishness." John Dewey, Ethics, in John Dewey: The Later Works: 1925-1953, Volume 7, ed. Jo Ann Boydson (Carbondale, IL: Southern Illinois University Press, 1985), 226.

8. For an interesting discussion of the significance of unlearning, see Marilyn CochranSmith, "Learning and Unlearning: The Education of Teacher Educators," Teaching and Teacher Education 19 (2003).

9. Jeff Frank, "James Baldwin's 'Everybody's Protest Novel': Educating Our Responses to Racism," Educational Philosophy and Theory, accessed May 16, 2011, http://www.tandfonline. com/doi/abs/10.1111/j.1469-5812.2011.00776.x.

10. Lawrie Balfour, The Evidence of Things Not Said: James Baldwin and the Promise of American Democracy (Ithaca, NY: Cornell University Press, 2001); George Shulman, American Prophecy: Race and Redemption in American Political Culture (Minneapolis: University of Minnesota Press, 2008); Jack Turner, "Awakening to Race: Ralph Ellison and Democratic Individuality," Political Theory 36, no. 5 (2008); Elizabeth Spelman, "Managing Ignorance," in Race and Epistemologies of Ignorance, eds. Sharon Sullivan and Nancy Tuana (Albany, NY: SUNY P, 2007); David Cerbone, "The Limits of Conservatism: Wittgenstein on 'Our Life' and 'Our Concepts,"' in The Grammar of Politics: Wittgenstein and Political Philosophy, ed. Cressida Heyes (Ithaca, NY: Cornell University Press, 2003).

11. An exception is Frank, "Educating our Responses to Racism."

12. This will be described in more detail below. For a related discussion, see Jeff Frank, "Can Perfectionism Withstand the Acknowledgment of Slavery?," Philosophy of Education Yearbook 2011 (2011).

13. James Baldwin, Collected Essays (New York: Library of America, 1988), 122.

14. For an interesting discussion of how these myths get played out in educational literature, see Anthony Brown, "'Same Old Stories': The Black Male in Social Science and Educational Literature, 1930s to the Present," Teachers College Record 113, no. 9 (2011).

15. While talk of truth may strike some readers as naïve and potentially indicative of a belief in what is referred to as discredited Enlightenment ideals, I don't think talk of truth and an acknowledgement of the role that power, for example, plays in the social practices of knowledge building are necessarily oppositional. For a good example of work that exemplifies this stance, see Miranda Fricker, "Feminism in Epistemology: Pluralism Without Postmodernism," in The Cambridge Companion to Feminism in Philosphy, eds. Miranda Fricker and Jennifer Hornsby (New York: Cambridge University 


\section{JEFF FRANK}

Press, 2000), and Miranda Fricker, Epistemic Injustice: Power and the Ethics of Knowing (New York: Oxford, 2007).

16. For a discussion of acknowledgement, see Stanley Cavell, The Claim of Reason (New York: Oxford University Press, 1979). The point here is that it is one thing to know that racism may affect society, social relationships and social opportunities, and that one may be a beneficiary of this racism; it is quite another to live that reality. To acknowledge racism-as I will show below-calls an individual to develop into a very different person than the one he or she currently is.

17. Baldwin, Essays, 277.

18. Ibid., 24.

19. Cora Diamond, "The Difficulty of Reality and the Difficulty of Philosophy," in Philosophy and Animal Life (New York: Columbia University Press, 2008).

20. Baldwin, Essays, 13.

21. Ibid., 338.

22. Ibid., 279.

23. Ibid., 339.

24. In a letter written to Baldwin after reading The Fire Next Time, Hannah Arendt notes that love is the "proudest possession of all pariahs." See Hannah Arendt, "The Meaning of Love in Politics: A Letter by Hannah Arendt to James Baldwin," accessed May 16, 2011, http:// hannaharendt.net/documents/baldwinII.html

25. Ibid., 341.

26. Michelle Alexander, The New Jim Crow: Mass Incarceration in the Age of Colorblindness (New York: New Press, 2010); Elizabeth Anderson, The Imperative of Integration (Princeton, NJ: Princeton University Press, 2010); Patricia Williams, Seeing a Color-Blind Future: The Paradox of Race (New York: Farrar, Straus and Giroux, 1998).

27. Though this statement sounds universal, it is meant to be illustrative of feelings that many of us may have from time to time. We might think — to take a glaring example-about the contentious discussion regarding how President Barack Obama is referred to by his detractors. Disentangling explicit racism from implied racism, and disentangling these from genuine critique, remains a challenge for many Americans.

Jeff Frank is at Sweet Briar College.

E-mail: jfrank@sbc.edu 